\title{
DISSERTACÕES EM ANTROPOLOGIA DEFENDIDAS NA UNIVERSIDADE FEDERAL DO RIO GRANDE DO SUL DE JULHO A NOVEMBRO DE 2000
}

\author{
BENEDETTI, Marcos Renato
}

Orientadora: Ondina Fachel Leal

Toda Feita: 0 Corpo e o Gênero das Travestis.

Este trabalho trata dos processos de transformação do gênero executados pelas travestis que se prostituem em Porto Alegre, Brasil. Procurou-se compreender, a partir das práticas de modificação e transformação das formas do corpo, as dinâmicas da construção do feminino neste grupo. Também analisou-se as relações entre travestis e seus maridos, seus clientes da prostituição e outras travestis, para melhor compreender os processos de aprendizado do gênero, que conforma seus gestos, suas posturas, suas sexualidades, suas relações, seus pensamentos e suas idéias. Entre as travestis, os valores do masculino e do feminino são construídos no e pelo corpo; elas constituem um caso paradigmático para análise das dinâmicas sociais de produção do gênero , por demonstrarem os conteúdos culturais deste processo.

\section{PACHECO, Janie Kiszewski}

Orientadora: Ondina Fachel Leal

Adoecer e Tratar-se: os percursos de cura em São José dos Ausentes/RS.

Esta dissertação procura, através do método etnográfico, analisar os percursos de cura existentes em São José dos Ausentes, uma pequena cidade no interior do Estado do Rio Grande do Sul. O foco deste trabalho são as relações estabelecidas entre os moradores e os agentes de cura locais, a partir das 
percepções nativas acerca do corpo, da doença e da saúde. Buscou-se também analisar as relações e as possíveis tensões entre esses agentes de cura.

\author{
ALTMANN, Lori \\ Orientador: Oscar Agüero
}

\title{
Maittaccadsama - Categorias de espaco e tempo como referenciais para a construção de identidade Kulina (Madija).
}

A presente dissertação trata do povo indígena Kulina, que se auto-denomina madija, e que vive na Amazônia Ocidental, entre os vales dos rios Purus e Juruá. Através de uma abordagem etnográfica, baseada na língua nativa e seus aspectos semânticos, busca apreender a concepção kulina a respeito de espaço e tempo, entendidos como categorias do pensamento humano. Parte da narrativa de sua história recente marcada pelo confronto com a frente extrativista da borracha e do caucho na região. Explicita, através da interpretação de narrativas e mitos, como as categorias de espaço e tempo kulina, cultural e historicamente informadas, expressam uma cosmovisão específica, que sofre uma ruptura a partir da penetração da empresa seringalista em seus territórios. Expõe como a identidade dos antepassados do povo kulina, centrada no sistema de manaco, instituição básica de sua cultura e referenciada ao centro da mata, passa por uma transformação como povo que vive hoje entre a floresta e o rio, na contradição que se estabeleceu entre o sistema de reciprocidade e o sistema hegemônico da sociedade dominante. A mudança para a margem do rio e para a marginalização social provocou uma ruptura na cosmovisão tradicional, levando à construção de uma nova identidade a partir de uma temporalidade e de uma espacialidade transformadas. 